\title{
Compositional analysis of fatty acids in cow's milk when feeding a complex additive based on activated diatomite
}

\author{
Venera Akhmetova, Svetlana Dezhatkina*, Asgat Muhitov, Natalya Sharonina \\ Ulyanovsk State Agrarian University named after P.A. Stolypin, Ulyanovsk, Russia
}

\begin{abstract}
The article presents the research results of the effect of activated diatomite as part of a complex supplement on the composition and ratio of saturated and unsaturated fatty acids in cow's milk. The experiments were carried out in a dairy farm on black-and-white cows. The additive includes a carrieractivated diatomite; fillers are DAPS-organic selenium, sunflower oil and feed yeast and diatomite crumbs. The supplement was included in the diet of cows at the rate of $2 \%$ of the dry matter of the diet once a day. The control group did not receive the supplement. The positive effect of the use of the additive on the composition of fatty acids in cow's milk was established. There was an increase in the fraction of saturated fatty acids, which indicates an increase in volatile fatty acids: acetate and 3-hydroxybutyrate. The use of a complex supplement based on activated diatomite contributed to an increase in concentration of capric, lauric, myristic, palmitic and margarine fatty acids. The use of additives for dairy cows helps to increase their productivity, improve the quality of milk composition due to the intensive conversion of feed nutrients.
\end{abstract}

\section{Introduction}

In order to obtain organic products in the field of dairy farming, the scientific search and development of new and highly effective feed products based on natural components are relevant [1-3].

Scientists' attention is drawn to the discovery of special properties of silicon-containing minerals: ion exchange, adsorption, detoxification, supply of silicon and mineral elements. The ability of silicon compounds to adsorb amino acids and protein provides their rapid absorption in the stomach and intestines and increases the assimilation of feed [4-5].

It is important to note that the bone tissue consists of silica, which gives it strength. Silicon helps to ensure the storage of calcium and other minerals in the bone; if silicon is removed from the diet, calcium is also removed from the bones. The regulatory role of silicon in body is significant. Mineral homeostasis is normalized and body absorbs the nutrients of the feed [6]. Any disbalance and a lack of silicon in body lead to disorders and contribute to the development of diseases: bone softening; diseases of eyes, teeth, claws, skin and hair, cartilage; stones in liver and kidneys; atherosclerosis [7].

In Russia, new deposits of silicon-containing rocks (zeolite, diatomite, and others) have been discovered, which are located in the zone of Middle Volga region (Ulyanovsk Region) [8-10].

\section{Materials and methods}

Scientific research is aimed at studying the effect of silicon-containing supplements on the animal's body, its productivity and product quality in order to obtain highquality organic products.

The aim of the work was to study the effect of silicon-containing complex supplement based on activated diatomite (deposits of the Ulyanovsk region) on the fatty acid composition of cow milk.

The subject of the study is a complex supplement that includes a carrier-activated diatomite and a filler: DAPSdiacetophenonyl selenide (organic selenium), sunflower oil and feed yeast, and diatomite crumbs (table 1).

Diatomite is a mineral from ancient seaweed, leaves of which are fossilized and 70-90\% consists of silicon. It contains oxides of iron and calcium, magnesium, copper chelates, manganese, zinc and vitamins of group B and $\mathrm{K}$ in a smaller amount. It has been proven [8] that feeding animals with natural diatomite helps to reduce diseases of digestive tract, excretion of metabolic products and toxic substances that have come with food and are formed as a result of digestion increases the absorption of feed nutrients, contributes to the increase of animal productivity [9-10].

DAPS-25k is an organic selenium that is used for all types of animals and birds, has low toxicity, makes up for the lack of selenium in the diet, serves as a hepatoprotector and a means for the prevention of mycotoxicosis. The composition of the complex additive is presented in table 1.

\footnotetext{
Corresponding author: dsw1710@yandex.ru
} 
Table 1. The composition of the additive

\begin{tabular}{|l|c|}
\hline \multicolumn{1}{|c|}{ Indicator, units } & Quantity \\
\hline Activated diatomite, $\%$ & 68,00 \\
\hline Feed yeast, $\%$ & 30,00 \\
\hline Premix diatomite, $\%$ & 2,00 \\
\hline Total & 100,00 \\
\hline
\end{tabular}

The experiments were conducted in the conditions of a dairy farm on black-and-white cows in the Ulyanovsk region by LLC "Agrofirma Tetyushskoe" for 100 days. Two groups of 50 cows were formed, the first - the control group, received only the basic diet. The second group was added to the diet once a day with a complex supplement in the amount of $2 \%$ of the dry matter (DM).

For the physiological experiment, according to the method of analogues, 5 cows were selected in a group, which on the 2 nd ... 3rd lactation was the same in live weight, physiological state, age, and productivity.

The animals were kept in the same conditions on a leash. Milk productivity was recorded daily, and control milking was carried out once a month. To determine the parameters, "Lactane 1-4" was used. The fatty acid composition of milk was studied using the gas chromatograph "GC-1000". The results were processed using the program "Statistika".

\section{Results and Discussion}

Balancing the diets of cows through a complex supplement helps to increase milk productivity. An increase in average daily milk yield by $24.7 \%$ (at $\mathrm{p}<0.05)$, milk fat - by $16.2 \%$ compared to table 2 analogues was revealed (table 2).

Table 2. Indicators of dairy productivity of cows when feeding a complex supplement

\begin{tabular}{|c|c|c|c|}
\hline Period & Indicator, units & $\begin{array}{l}1 \text { group, } \\
\text { contro } \\
1\end{array}$ & $\begin{array}{l}2 \text { group, } \\
\text { experim } \\
\text { ent }\end{array}$ \\
\hline \multirow{3}{*}{$\begin{array}{l}\text { Before the } \\
\text { experiment, } 3 \\
4 \text { months of } \\
\text { lactation }\end{array}$} & $\begin{array}{l}\text { Average daily milk } \\
\text { yield per } 1 \text { cow, } \mathrm{kg}\end{array}$ & $\begin{array}{c}19,5 \pm \\
0,93\end{array}$ & $\begin{array}{c}19,44 \pm \\
0,24\end{array}$ \\
\hline & Fat content of milk, $\%$ & $\begin{array}{c}4,16 \pm \\
0,17 \\
\end{array}$ & $\begin{array}{c}4,13 \pm \\
0,12 \\
\end{array}$ \\
\hline & Butterfat, kg & $\begin{array}{c}0,81 \pm \\
0,05 \\
\end{array}$ & $\begin{array}{c}0,80 \pm \\
0,03 \\
\end{array}$ \\
\hline \multirow{3}{*}{$\begin{array}{l}\text { The } \\
\text { experiment, } 4 \\
5 \text { months of } \\
\text { lactation }\end{array}$} & $\begin{array}{l}\text { Average daily milk } \\
\text { yield per } 1 \text { cow, kg }\end{array}$ & $\begin{array}{l}16,67 \\
\pm 0,87\end{array}$ & $\begin{array}{c}20,78 \\
\pm 1,29^{*}\end{array}$ \\
\hline & Fat content of milk, $\%$ & $\begin{array}{c}4,07 \pm \\
0,12\end{array}$ & $\begin{array}{c}3,81 \pm \\
0,12\end{array}$ \\
\hline & Butterfat, kg & $\begin{array}{c}0,68 \pm \\
0,05 \\
\end{array}$ & $\begin{array}{c}0,79 \pm \\
0,06 \\
\end{array}$ \\
\hline \multirow{3}{*}{$\begin{array}{l}\text { The } \\
\text { experiment, } 5 \\
6 \text { months of } \\
\text { lactation }\end{array}$} & $\begin{array}{l}\text { Average daily milk } \\
\text { yield per } 1 \text { cow, } \mathrm{kg}\end{array}$ & $\begin{array}{c}17,56 \\
\pm 0,8\end{array}$ & $\begin{array}{c}17,66 \pm 0 \\
, 87\end{array}$ \\
\hline & Fat content of milk, $\%$ & $\begin{array}{l}3,99 \pm \\
0,16\end{array}$ & $\begin{array}{l}4,34 \pm \\
0,19\end{array}$ \\
\hline & Butterfat, kg & $\begin{array}{c}0,69 \pm \\
0,03\end{array}$ & $\begin{array}{c}0,76 \pm \\
0,05\end{array}$ \\
\hline
\end{tabular}

Note: $*$ - $(\mathrm{p}<0.05)$ compared to the control
The content of non-fat milk solid (NFMS) in the milk of cows of the experimental group was 9.74 \pm 0.10 , compared to $9.61 \pm 0.08$ in the control. This indicator shows the naturality of milk, high content of dry substances and a smaller amount of water. The content of heavy metals such as cadmium and lead in milk of cows in all groups was within the permissible limits $(\mathrm{Cd}-$ $0.03 \mathrm{mg} / \mathrm{kg}, \mathrm{Pb}-0.1 \mathrm{mg} / \mathrm{kg}$ ). The use of supplement contributed to a decrease in concentration of these elements in milk of cows of the experimental group by $13 \ldots 16 \%$ compared to the control

At the beginning of the experiment, the average daily milk yield in all groups was at the same level within $19.55 \mathrm{~kg}$. The fat content of the milk was $4.13 \%$. The amount of milk fat was $0.80 \mathrm{~kg}$, the protein content in milk $-2.86 \%$, the amount of protein $-0.56 \mathrm{~kg}$ and SOMO $-9.39 \%$. The inclusion of a modified diatomite supplement into the body of dairy cows contributed to the production of more and better quality milk. An increase in the average daily milk yield by $24.7 \%$ (at $\mathrm{p}<0.05)$, milk fat - by $16.2 \%$ compared to analogs was revealed (fig. 1).

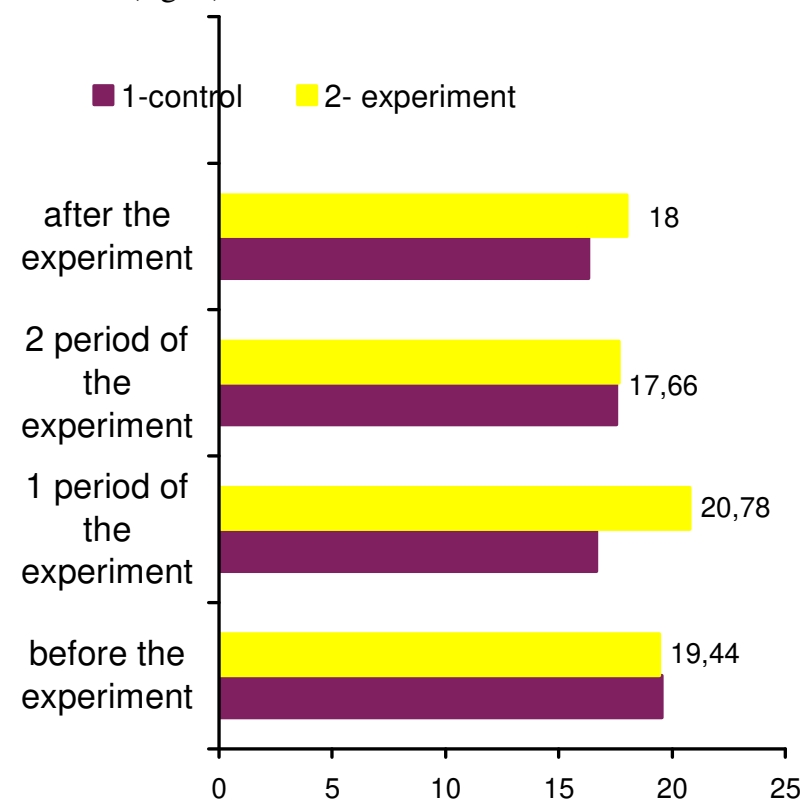

Fig. 1. Dynamics of the average daily milk yield of cows when feeding the supplement, $\mathrm{kg}$

In the course of the research, it was noted that feeding the supplement to animals of the 2nd group did not contribute to the change in the fat content of milk. This parameter was stable and varied little, on average it was within the range of $4.13 \ldots 4.34 \pm 0.19 \%$. The use of the supplement did not have a noticeable effect on the protein level in the milk of cows. This indicator in the milk of cows of the experimental group was in the range of $\quad 3.81 \pm 0.12 \ldots 4.34 \pm 0.19 \quad \% \quad$ against $4.07 \pm 0.12 \ldots 3.99 \pm 0.16 \%$ in the control group.

The content of milk solids residue in the milk of cows of the experimental group was $9.74 \pm 0.10$, against $9.61 \pm 0.08$ in control. This indicator points out that milk is natural, there is high content of solids, and less water. The content of heavy metals, like cadmium and lead in cow's milk in all groups was normal $(\mathrm{Cd}-0.03 \mathrm{mg} / \mathrm{kg}$, 
$\mathrm{Pb}-0.1 \mathrm{mg} / \mathrm{kg}$ ). Using supplements helps to reduce the concentration of these elements in cows milk of the experiment group by $13 \ldots 16 \%$ against the control group.

It is known that mineral elements in the cows' milk average $0.75 \%$ of the total composition of milk. During the first period of feeding the supplement, there was a tendency to an increase in the level of calcium $(\mathrm{Ca})$ in cow's milk of the second group by $3 \%$, which amounted to $89.1 \pm 4.82 \mathrm{mg} \%$.

This occurred against the background of a decrease in the concentration of phosphorus $(\mathrm{P})$ by $8.6 \%$ to $80.5 \pm 13.48 \mathrm{mg} \%$. When using the supplement the $\mathrm{Ca} / \mathrm{P}$ ratio increased by $9.3 \%$ and amounted to $1.118 \pm 0.045$. At the same time, the concentration of iron $(\mathrm{Fe})$ increased by $17.9 \%$, up to $1.079 \pm 0.174 \mathrm{mg} / \mathrm{kg}$ and had a pronounced tendency to decrease: zinc ( $\mathrm{Zn})$ to $1.541 \pm 0.062$ and copper $(\mathrm{Cu})$ - to $0.091 \pm 0.003 \mathrm{mg} / \mathrm{kg}$.

All indicators were within the physiological norm and are compared with the control. The data points that animals had pronounced deficiency of $\mathrm{Cu}$ and $\mathrm{Zn}$ in the ratio. Due to the fact, the soils of the Ulyanovsk region, where animal feed was grown, are poor in these microelements. The inclusion of supplement based on modified diatomite in ratio of cows contributed to the balancing of mineral homeostasis in the organism of lactating cows

The prolonging effect of the additive, which is associated with the accumulation of the reserve of mineral elements in the body of animals, is noted. It was found that feeding a complex supplement to cows of the second group had a favorable effect on the quantity and quality of fatty acids in milk, table 3 .

An increase in saturated fatty acids by $4.0 \%$ was revealed, in particular: Caprylic - by $6.7 \%$, lauric - by $12.3 \%$, $(\mathrm{P}<0.05)$, myristic - by $13.3 \% \quad(\mathrm{P}<0.05)$, palmitic - by $17.1 \%,(\mathrm{P}<0.05)$ in the fat fraction of the milk of cows of the experimental group compared to the control. At the same time we observed lower concentration of stearic acid by $27.3 \%(\mathrm{P}<0,05)$ and arachidic - by $27.6 \%(\mathrm{P}<0.05)$. Under the influence of the additive, favorable conditions are created for the activity of the scar microflora.

These indicators indicate an increase in the number of amylolytic microflora and the active synthesis of volatile fatty acids (VFA) in the rumen of cows, in particular acetate and 3-hydroxybutyrate.

Active synthesis of these acids is possible only with an increase in the number of protozoa that synthesize microbial protein and the level of urease. The presence of sunflower oil in the additive increases the fraction of saturated fatty acids in the milk of cows of the experimental group.

The content of monounsaturated and polyunsaturated fatty acids in cow's milk when feeding a complex supplement is in table 4.
Table 3. The content of saturated fatty acids in the milk of cows when feeding a complex supplement

\begin{tabular}{|c|c|c|c|}
\hline Indicator & $\begin{array}{l}\text { GOST } \\
32261- \\
2013\end{array}$ & $\begin{array}{l}1 \text { group } \\
\text { control }\end{array}$ & $\begin{array}{l}2 \\
\text { group } \\
\text { experiment }\end{array}$ \\
\hline Butyric $(\mathrm{C} 4: 0)$ & $2.4-4.2$ & $\begin{array}{l}2.987 \\
\pm 0.171\end{array}$ & $\begin{array}{l}2.783 \\
\pm 0.098\end{array}$ \\
\hline Caproic (C6:0) & $1.5-3.0$ & $\begin{array}{l}2.193 \\
\pm 0.105\end{array}$ & $\begin{array}{l}2.170 \\
\pm 0.140\end{array}$ \\
\hline Caprylic (C8:0) & $1.0-2.0$ & $\begin{array}{l}1.440 \\
\pm 0.074\end{array}$ & $\begin{array}{l}1.457 \\
\pm 0.088\end{array}$ \\
\hline $\begin{array}{l}\text { Decanoic } \\
(\mathrm{C} 10: 0)\end{array}$ & $2.0-3.8$ & $\begin{array}{l}3.413 \\
\pm 0.159\end{array}$ & $\begin{array}{l}3.643 \\
\pm 0.113\end{array}$ \\
\hline Lauric (C12:0) & $2.0-4.4$ & $\begin{array}{l}3.910 \\
\pm 0.137\end{array}$ & $\begin{array}{l}4.390 \\
\pm 0.099 *\end{array}$ \\
\hline Myristic (C14:0) & $\begin{array}{l}8.0- \\
13.0\end{array}$ & $\begin{array}{l}11.630 \\
\pm 0.295\end{array}$ & $\begin{array}{l}13.180 \\
\pm 0.450 *\end{array}$ \\
\hline Palmitic (C16:0) & $\begin{array}{l}21.0- \\
33.0\end{array}$ & $\begin{array}{l}25.280 \\
\pm 1.632\end{array}$ & $\begin{array}{l}29.593 \\
\pm 1.781\end{array}$ \\
\hline Stearic (C18:0) & $\begin{array}{l}8.0- \\
13.5\end{array}$ & $\begin{array}{l}13.477 \\
\pm 0.961\end{array}$ & $\begin{array}{l}9.803 \\
\pm 0.948 *\end{array}$ \\
\hline $\begin{array}{l}\text { Arachidic } \\
(\mathrm{C} 20: 0)\end{array}$ & 0.3 & $\begin{array}{l}0.203 \\
\pm 0.015\end{array}$ & $\begin{array}{l}0.147 \\
\pm 0.012 *\end{array}$ \\
\hline $\begin{array}{l}\text { Margaric } \\
(\mathrm{C} 17: 0)\end{array}$ & $\begin{array}{l}0.02- \\
1.05\end{array}$ & $\begin{array}{l}0.567 \\
\pm 0.023\end{array}$ & $\begin{array}{l}0.573 \\
\pm 0.055\end{array}$ \\
\hline Behenic (C22:0) & 0.1 & $\begin{array}{l}0.097 \\
\pm 0.007\end{array}$ & $\begin{array}{l}0.070 \\
\pm 0.010\end{array}$ \\
\hline $\begin{array}{l}\text { Total of } \\
\text { saturated }\end{array}$ & & $\begin{array}{l}65.197 \\
\pm 0.0809\end{array}$ & $\begin{array}{l}67.810 \\
\pm 1.084\end{array}$ \\
\hline
\end{tabular}

Note: * - $(\mathrm{p}<0.05)$ compared to the control

Table 4. The content of monounsaturated and polyunsaturated fatty acids in cow's milk when feeding a complex supplement

\begin{tabular}{|l|l|l|}
\hline Indicator & $\begin{array}{l}1 \text { group } \\
\text { control }\end{array}$ & $\begin{array}{l}\text { 2 group } \\
\text { experiment }\end{array}$ \\
\hline Palmitoleic (C16:1) & $1.157 \pm 0.119$ & $1.167 \pm 0.137$ \\
\hline Oleic (C18:1) & $23.710 \pm 0.52$ & $21.410 \pm 1.22$ \\
\hline Decenoic (C10:1) & $0.290 \pm 0.032$ & $0.343 \pm 0.012$ \\
\hline Myristoleic (C14:1) & $0.733 \pm 0.103$ & $0.993 \pm 0.058$ \\
\hline Gondoic (C20:1) & $0.063 \pm 0.013$ & $0.060 \pm 0.015$ \\
\hline $\begin{array}{l}\text { Total } \\
\text { monounsaturated }\end{array}$ & $\mathbf{2 5 . 9 5 3 \pm 0 . 2 8}$ & $\mathbf{2 4 . 0 4 0 \pm 1 . 1 3}$ \\
\hline Eicosadienoic (C20:2) & $0.170 \pm 0.006$ & $0.167 \pm 0.012$ \\
\hline Linoleic (C18:2) & $4.950 \pm 0.530$ & $4.230 \pm 0.372$ \\
\hline Linolenic (C18:3) & $0.490 \pm 0.021$ & $0.440 \pm 0.009$ \\
\hline Linolenic c1 & $0.123 \pm 0.007$ & $0.090 \pm 0.006 *$ \\
\hline Linolenic c2 & $0.367 \pm 0.015$ & $0.357 \pm 0.012$ \\
\hline $\begin{array}{l}\text { Total } \\
\text { polyunsaturated }\end{array}$ & $\mathbf{5 . 6 1 0} \pm \mathbf{0 . 5 4 9}$ & $\mathbf{4 . 8 4 3 \pm 0 . 3 7 0}$ \\
\hline Other & $\mathbf{3 . 2 4 0} \pm \mathbf{0 . 0 7 1}$ & $\mathbf{3 . 3 7 3} \pm \mathbf{0 . 0 7 8}$ \\
\hline
\end{tabular}

Note: $*$ - $(\mathrm{p}<0.05)$ compared to the control

In the cow's milk of the experimental group, there was a decrease in the concentration of monounsaturated fatty acid by $7.4 \%$ because of the oleic acid. At the same time was observed is lower concentration polyunsaturated fatty acids by $13.7 \%$, because of 
linoleic - by $14.5 \%$ and linolenic acid - by $10.2 \%$. The indicators are shown in comparison with the control.

The study of the organoleptic properties of milk showed that there were no special differences between the groups in the color of milk. All samples had a white color due to the presence of the calcium salt of casein and fat balls. The taste was determined by taking a mouthful of milk at room temperature and rinsing the oral cavity to the root of the tongue. There were no differences in taste in the samples between the groups, and the taste of all milk samples was pleasant.

The smell in the milk was determined at room temperature. All samples had a specific smell inherent in milk, no differences were found.

The consistency of the milk was determined by slowly pouring it from one glass to another. It was found that the consistency of the milk samples under study is homogeneous.

The determination of the admixture of abnormal milk was carried out according to the following method: 1 $\mathrm{cm}^{3}$ of thoroughly mixed milk was added to the PMK-1 plate and $1 \mathrm{~cm}^{3}$ of a $2.5 \%$ solution of the Mastoprim preparation was added. The milk with the preparation was intensively mixed with a glass rod for 10 seconds, the resulting mixture was raised with a stick up by $5 \ldots 7$ $\mathrm{cm}$, and the results were evaluated. All milk samples contained up to 500 thousand somatic cells in $1 \mathrm{~cm}^{3}$, which corresponds to the norm, no differences between the groups were established.

During the experiment, all the animals were clinically healthy and kept in a territory that was safe from infectious and other diseases common to humans and animals. It is known that $1 \mathrm{ml}$ of fresh milk can contain hundreds to thousands of bacteria. Milk from a healthy cow usually contains less than $10 \mathrm{CFU} / \mathrm{ml}$ of microbes (CFU / ml-colony-forming units show the number of viable microorganisms per unit volume).

It is possible that in the process of milking (not a satisfactory sanitary condition of milking machines), storage, and processing, the number of microorganisms in milk increases many times. We proved that the resulting milk was safe in microbiological terms, and cannot cause harm to the human body.

Microbiological analysis of milk samples from animals of all groups allowed us to find out that no causative agents of mastitis and other infectious agents were found in the samples. The presence of such microflora as staphylococcus aureus, streptococci, BPH, pseudomonas aeruginosa, fungi of the genus Salida was not detected. This is confirmed by the test for microbial safety of milk, which determines the number of mesophilic aerobic and facultative anaerobic microorganisms (CMAFAnM or total bacterial contamination).

It is important to note that such a factor as seasonality is important. In winter, the activity of microflora is reduced, and in the warm season, it increases. It was revealed that in the winter-spring period - at the beginning of the use of additives, the total level of microbial cells of CMAFAnM for cows of the 2nd group reached $4.9 \times 104 \mathrm{CFU} / \mathrm{ml}$, against $7.9 \times 104$ $\mathrm{CFU} / \mathrm{ml}$ in the control.

\section{Conclusion}

The use of a complex supplement based on activated diatomite for dairy cows contributed to the improvement of composition of milk fatty acids in the direction of increasing the concentration of capric (C10:0), lauric (C12:0), myristic (C14:0), palmitic (C16:0) and margaric (C17:0) fatty acids. The use of the supplement for dairy cows helps to increase their productivity, improve the quality of milk composition due to the intensive conversion of feed nutrients.

\section{References}

1. V.E. Ulitko, A.V. Kornienko, E.A. Savina, Vestnik of Ulyanovsk state agricultural academy, 4(44) (2018)

2. P.C. Beukes, P. Gregorini, G. Waghorn, D.R. Selbie, New Zealand Journal of Animal Science and Production, 78 (2018)

3. C.M. Dschaak, J.S. Eun, A.J. Young, R.D. Stott, S. Peterson, The Professional Animal Scientist, 26 (2010)

4. E.V. Chernyshkova, V.E. Ulitko, O.A. Desyatov, Vestnik of Ulyanovsk state agricultural academy, 2(46) (2019)

5. N.A. Lyubin, S.V. Dezhatkina, V.V. Akhmetova, A.Z. Mukhitov, M.E. Dezhatkin, Sh.R. Zyalalov, Russian Journal of Agricultural and SocioEconomic Sciences, 1 (97) (2020)

6. A.D. Stelwagen, P.C. Beukes, C. Hemmings, Animal Production Science, 61(6) (2020)

7. P Bosi, D. Creston, L. Casini, Italian Journal of Animal Science, 1 (2002)

8. Sh.R. Zyalalov, S.V. Dezhatkina, A.Z. Mukhitov, M.E. Dezhatkin, S.V. Merchina, L.P. Pulcherovskaya, Scientific notes of Kazan State Academy of Veterinary Medicine named after N. E. Bauman, 3 (2020)

9. M. Kithome, J.W. Paul, L.M. Lavkulich, A.A. Bomke, Communications in Soil Science and Plant Analysis, 30 (1999)

10. D. Papaioannou, P.D. Katsoulos, N. Panousis, H. Karatzias, Microporous and Mesoporous Materials, 84 (2005) 